\title{
Unrecognized lupus vulgaris, revealed by its treatment
}

\author{
Nadia Baali', Aymane Ismail'², Ouafa Hocar ${ }^{1}$, Nadia Akhdari'1, Hanane Rais ${ }^{2}$, Said Amal ${ }^{1}$
}

\author{
${ }^{1}$ Department of Dermatology, Mohammed VI CHU, Marrakech, Morocco, ${ }^{2}$ Department of Pathological Anatomy and \\ Cytology, CHU Mohamed VI, Marrakech, Morocco
}

Corresponding author: Dr. Nadia Baali, E-mail: nadia.baali@outlook.fr

\begin{abstract}
A 49-year-old woman, without medical or family history, presents since 6 months ago an erythematous-squamous, papular plaque at the centro-facial level that increased very progressively. The physical examination was normal including pleuropulmonary, abdominal and osteo-articular examination. Everything was evolving in a context of apyrexia and conservation of the general state. During her hospitalization, the cutaneous biopsy found a granuloma with epitheliod and giant cells without caseous necrosis. The tuberculin IDR was negative. The search of Koch bacillus was negative in the cutaneous samples and sputum. TPHA/VDRL and HIV serologies were normal. The bacteriological and mycological examination of the biopsy fragment was negative. The expert gene to identify Mycobacterium tuberculosis was negative and also the smears to research leishmania bodies were negative. Despite the absence of diagnosis evidence, an anti-tuberculosis treatment; 2RHZE/4RH regimen, was prescribed and a spectacular amelioration was noted during and many months after the end of the treatment. So, the response to the treatment was the only diagnosis evidence for the lupus vulgaris.
\end{abstract}

Key words: Granuloma; Cutaneous tuberculosis; Infection disease of skin

\section{INTRODUCTION}

Cutaneous Tuberculosis (TB) is uncommon; it represents $2 \%$ of extra-pulmonary localizations and often poses diagnosis problems. Lupus vulgaris(LV) is a form conventionally linked to the reactivation of an endogen focus. We report an observation of unrecognized $\mathrm{LV}$, revealed by its treatment.

\section{CASE REPORT}

A 49-year-old, housewife, of low socioeconomic status, from Marrakech, without particular pathological history, presents over 6 months an erythematous squamous papular plaque at the centro-facial level that had been growing progressively.

At her admission, there was an erythematous, ulcerated placard, $10 \times 8.5 \mathrm{~cm}$, recovered with crust and oozing on which was many fold flubbydermic micronodules brown-yellowish at vitro-pressure, giving to lesion an lupoid aspects (Fig. la).
Otherwise, the rest of the clinical examination was normal including pleuro-pulmonary, digestive and osteo-articular examination. Everything was evolving in a context of apyrexia and conservation of the general state. Cutaneous biopsy found a granuloma with epitheliod and giant cells without caseous necrosis (Figs. 2a and 2b).

The tuberculin IDR was negative. The search for Koch's bacillus was negative on cutaneous samples and sputum. The TPHA/VDRL and HIV serologies were negative. Bacteriological, mycological examinations of the biopsy fragment were negative. The expert gene to identify Mycobacterium tuberculosis was negative and also the smears to search leishmania bodies were negative. The pulmonary radiography, the abdominal and pelvic echography was normal.

The diagnosis of cutaneous leishmaniasis was initially evocated despite the negativity of the cutaneous smear and the patient was treated with metronidazole $750 \mathrm{mg}$ per day for 3 months but without any improvement.

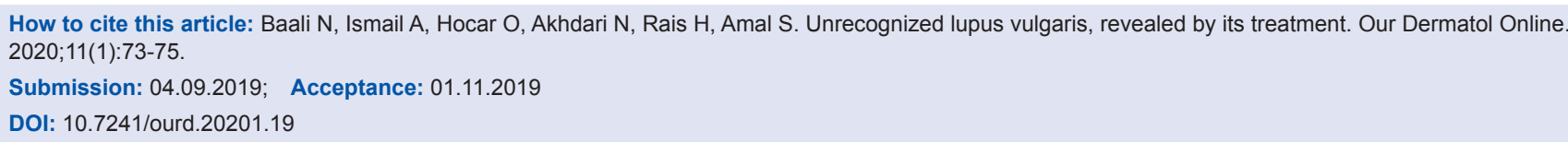




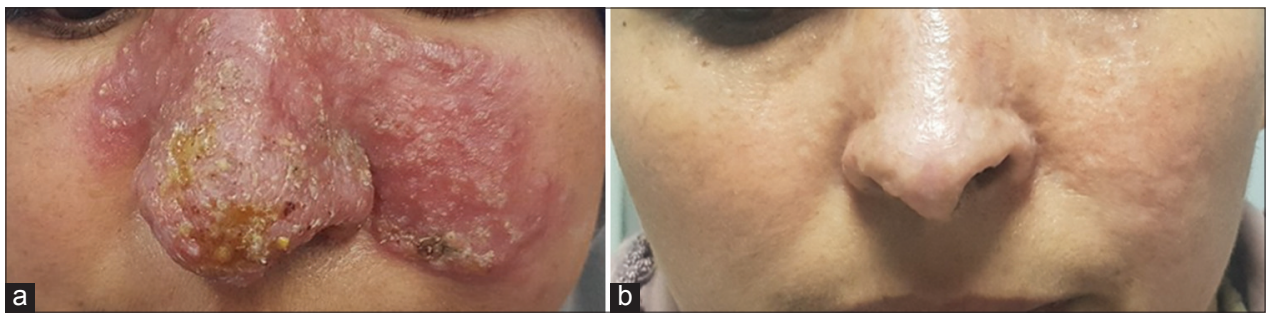

Figure 1: An erythematous squamous papular plaque at the centro-facial level (a), regression of the lesion after 6 months of antituberculous treatment (b).

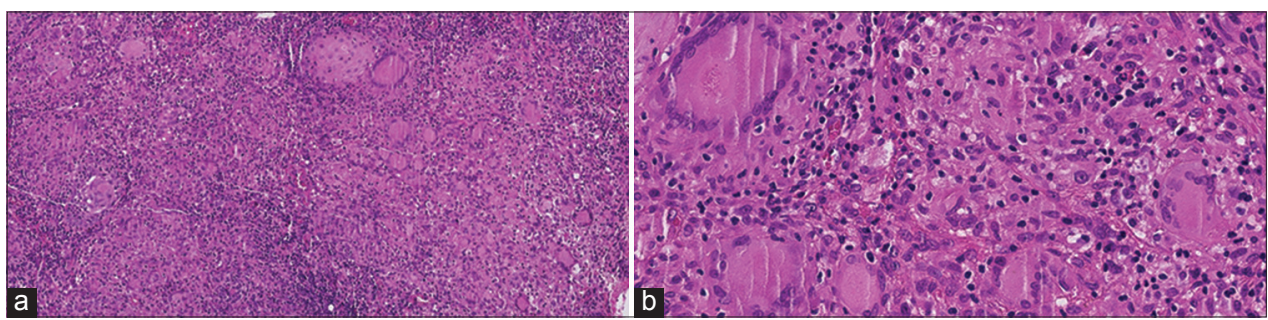

Figure 2: Granuloma structures (hematoxylin and eosin * 20) (a), infiltration in the subcutaneous tissue, granuloma arrows indicate multinuclear giant cells (hematoxylin and eosin * 40) (b).

$\mathrm{LV}$ was also evoked in front of the origin of the patient, the lupoid aspect at the vitro pression as well as the granulomatous aspect in the histology. The patient was treated with an anti-tuberculosis treatment with 2RHZE/4RH(first 2 months of isoniazid, rifampicin, pyrazinamide, ethambutol quadruple treatment plus 4 months of isoniazid and rifampicin combination). After the end of the treatment, a complete disappearance of the lesion was noted (Fig. lb).

\section{DISCUSSION}

$\mathrm{TB}$ is uncommon and much less frequent than the other localization of Tuberculosis disease [1] LV represents the most common form in the Western countries. It affects the female sex more frequently [2]. Its favorite localization is the face, especially the nose and cheeks. It is almost single, rarely multiple $[3,4]$. The diagnosis of certainly of the LV remains difficult. In our context, the culture and methods of rapid detection of Mycobacterium tuberculosis by genomic amplification (PCR) are not available; it is usually in front of many epidemiological, clinical, paraclinical arguments, that the diagnosis is often retained. Indeed, the Mycobacterium tuberculosis is rarely found at the direct examination and at the culture $[5,6]$.

Clinically, LV can be confused with cutaneous leishmaniasis, leprosy, tertiary syphilis...; thus, the diagnosis can be even more difficult in the presence of a tuberculoid granuloma without caseous necrosis in the histology, which can be observed in many nontuberculous dermatoses [7].

The therapeutic decision must take into account mainly the epidemiological and clinical arguments, especially the existence of lupomas at the vitro- pressure test at the periphery of every dermatosis which extends very slowly, paraclinically by a positive tuberculin IDR, histology and a pulmonary radiography evocative and especially a rapid evolution under antituberculosis allowing to retain the diagnosis [8].

However, the response to the specific anti-tuberculosis treatment may be the only evidence to the diagnosis of $\mathrm{TB}$ as in our case [9].

\section{CONCLUSION}

The Lupus vulgaris is an etiology to consider ahead of an old cutaneous lesion in our country where the prevalence of cutaneous tuberculosis remains high despite the negativity of the etiological assessment.

\section{Consent}

The examination of the patient was conducted according to the Declaration of Helsinki principles.

\section{REFERENCES}

1. Sellami K, Boudaya S, Chaabane H, Amouri M, Zahaf A, Mseddi M, et al. Lupus tuberculeux: à propos d'une série de 29 cas. Ann Dermatol Vénéréol. 2014;141:S448-9. 
2. Chialia A, Khelila A, Mahmoudia A, Sahnouna FZ, Askloua S, Cherrak $\mathrm{H}$, et al. Un lupus tuberculeux révélant une tuberculose pulmonaire: à propos d'un cas. Ann Dermatol Vénéréol. 2018;145:A47-8.

3. Verma S, Verma G, Shanker V, Tegta GR, Sharma A, Pandey ML. Facial lupus vulgaris of bilateral periorbital skin and conjunctiva: a case report and brief review. Indian J Med Microbiol. 2015;33:168-71.

4. Kane A, Dereure O, Guilhou JJ. Lupus tuberculeux multifocal. Ann Dermatol Venereol. 1996;123:118-21.

5. Striegel AK, Nazzal R, Fabri M, Rietschel E, Dötsch J, Mauch C, et al. Two cases of lupus vulgaris in childhood and review of the clinical challenges. Klin Padiatr. 2014;226:40-3.

6. Boudghene Stamboul OB, Dib Lachachi A. La tuberculose cutanée: toujours un problème d'actualité et de santé publique en Algérie: à propos de 7 observations récentes. Ann Dermatol Vénéréol. 2018;145:A32.
7. Zahaf A, Turki H, Masmoudi A. Lupus tuberculeux. Ann Dermatol Venereol. 2004;131:503.

8. Kane A, Niang SO, Cissé M, Sy TN, Diallo M, Dieng MT, Ndiaye B. Tuberculose cutanée à Dakar: à propos de 151 cas. Mali Med. 2010;XXV:14-7.

9. Sehgal VN, Sardana K, Sharma S. Inadequacy of clinical and/or laboratory criteria for the diagnosis of lupus vulgaris, re-infection cutaneous tuberculosis: fallout/implication of 6 weeks of antitubular therapy (ATT) as a precise diagnostic supplement to complete the scheduled regimen. J Dermatol Treat. 2007;11:1-4.

Copyright by Nadia Baali, et al. This is an open-access article distributed under the terms of the Creative Commons Attribution License, which permits unrestricted use, distribution, and reproduction in any medium, provided the original author and source are credited.

Source of Support: Nil, Conflict of Interest: None declared 